effect on cerebral electrogenesis. The relation between plasma electrolyte changes and increase in slow activity in the E.E.G. showed some individual variations, but we were not able to measure total body or urinary electrolyte values, osmolality of plasma or urine, or the rate at which these metabolic disturbances evolved. Differences in intravenous fluids given ( $5 \%$ dextrose, 0.09 or $0.18 \% \mathrm{NaCl} /$ dextrose solution) did not affect substantially the general cycle of events. Neither the patient's age nor the type of operation appeared to influence the degree or the timing of the postoperative metabolic and E.E.G. changes.

In conclusion, it has been our experience that a generalized increase in slow activity in the E.E.G. occurs between the first and the fourth day after heart surgery. The E.E.G. changes are fully reversible, in contrast to the effects of severe cerebral anoxia. The clinical evaluation of an excess of slow activity in the E.E.G. after cardiac surgery should take into account the patient's metabolic state, and particularly alterations of plasma electrolytes with hyponatraemia.

This work was aided in part by grants from the Commonwealth Fund and the United Health Foundations (G. H. G.) and the Joint Research Board, the Hospital for Sick Children, London (A. H.). We wish to express our thanks to the staff of the thoracic unit and the department of chemical pathology, the Hospital for Sick Children.

\section{REFERENCES}

Aronstam, E. M., Schmidt, C. H., and Jenkins, E. (1953). Ann. Surg., $137,316$.

Cadilhac, J., and Ribstein, M. (1961). Wld Neurol., 2, 296.

D'Angelo, G. J., Murdaugh, H. V., and Sealy, W. C. (1958). Surg. Gynec. Obstet., 106, 87.

Dodge, P. R., Crawford, J. D., and Probst, J. H. (1960). Arch. Neurol., 3, 513 .

Epstein, F. H., Levitin, H., Glaser, G., and Lavietes, P. (1961). New Engl. F. Med., 265, 513 .

Funck-Brentano, J. L., Lossky-Nekhorocheff, I., and Altman, J. (1960). Electroenceph. clin. Neurophysiol., 12, 185.

Gastaut, H., and Meyer, J. S. (Editors) (1961). Cerebral Anoxia, and the Electroencephalogram. Springfield, Illinois.

Goodyer, A. V. N., and Glenn, W. W. L. (1955). Circulation, 11, 584.

Leaf, A., and Roth, S. I. (1965). New Engl. 7. Med., 273, 1039.

Margerison, J. H., Anderson, W. McC., and Dawson, J. (1964). Electroenceph. clin. Neurophysiol., 17, 540 .

Moore, F. D. (1953). Ann. Surg., 137, 289.

Pampiglione, G. (1956). Proc. electrophysiol. Technol. Ass., 7, No. 1, p. 20 .

Pampiglione, G. (1965). Lancet, 2, 263.

Wilson, G. M. (1959). In Clinical Effects of Electrolyte Disturbances, edited by E. J. Ross, p. 194. London.

Wilson, G. M., Edelman, I. S., Brooks, L., Myrden, J. A., Harken, D. E., and Moore, F. D. (1954). Circulation, 9, 199.

\title{
Chromosomes and Transformation of Lymphocytes in Lymphoproliferative Disorders
}

\author{
SYLVIA D. LAWLER,* M.D., M.C.PATH.; C. R. PENTYCROSS, † M.B., B.CH. ; B. R. REEVES, $\ddagger$ B.SC.
}

Summary : In chronic lymphocytic leukaemia the $\checkmark$ majority of circulating lymphocytes which responded to phytohaemagglutinin in vitro were found to have normal karyotypes. A minor population of cells in patients treated with chemotherapy had an increased number of chromosomal rearrangements as compared with cells from normal controls and untreated patients with chronic lymphocytic leukaemia. Probably bonemarrow and lymph-node cells also had a normal karyotype.

In the other lymphoproliferative disorders the peripheral blood lymphocytes had either normal karyotypes or chromosomal abnormalities attributable to treatment, even in those cases where the tumour cells of involved lymph nodes were known to have abnormal karyotypes.

It was possible that circulating tumour cells were present in one case.

- Senior Lecturer.

† Leukaemia Research Fellow.

$¥$ Research Assistant.

Department of Clinical Research, Royal Marsden Hospital and Institute of Cancer Research, London S.W.3.

\section{Introduction}

In the lymphoproliferative disorders specific chromosomal abnormalities of the circulating lymphocytes have not been reported (Fitzgerald and Adams, 1965). An inherited constitutional abnormality, involving a deletion of the short arm of a group $\mathrm{G}$ chromosome, has been described in several members of a family, two of whom developed chronic lymphocytic leukaemia (Gunz et al., 1962). Since transmissible morphological variants of chromosomes are found in normal individuals such an association could be fortuitous. In subsequent cytogenetic studies of 11 other families with leukaemic sibs no further inherited chromosomal abnormalities have been observed (Fitzgerald et al., 1966). On the other hand, Goh (1967), exploiting the fact that the yield of mitoses is increased in lymphocyte cultures from patients with chronic lymphocytic leukaemia if the culture time is prolonged beyond the usual three days, claimed that even in untreated patients $40 \%$ of the karyotypes of cells with 46 chromosomes were rearranged (pseudodiploid).

This paper records the results of chromosome studies on the peripheral blood lymphocytes of patients with chronic lymphocytic leukaemia and other lymphoproliferative disorders, and on a series of normal controls. In most instances the lymphocytes 
of patients whose chromosomes were studied have also been tested for the response to stimulation with phytohaemagglutinin. In addition, chromosomal analyses were made of bone marrow aspirates from some of the patients and of lymph node biopsies from others.

\section{Materials and Methods}

\section{Classification of the Patients}

The twenty-nine patients studied were classified into five groups by using the following criteria:

(a) Chronic Lymphocytic Leukaemia (16 patients).-The classification was that of Galton (1963)-namely, a peripheral blood lymphocyte count of $5,000 / \mathrm{cu}$. mm. or over, lymphocytes forming $25 \%$ or more of the bone marrow cells. In this condition the normal architecture of the affected lymph nodes is typically replaced by sheets of small lymphocytes.

(b) Lymphocytic Lymphoma (5 patients).-The lymph node histology was similar to that found in chronic lymphocytic leukaemia, but the peripheral blood lymphocyte count was normal and an increase of lymphocytes in the bone marrow was not invariably present.

(c) Follicular Lymphoma (4 patients).-The lymph node histology showed neoplastic nodular aggregates which, on cursory examination, resembled large follicles.

(d) Reticulum-cell Sarcoma ( 3 patients). - The normal architecture of the lymph node(s) was replaced by clusters of reticulum cells.

(e) Lymphosarcoma ( 1 patient).-This classification depended on the presence of a primary malignant lymphomatous focus, in the case examined extra-nodal, having poorly differentiated lymphocytes and invasion of surrounding structures.

Difficulties were experienced in classification of the patients into categories $b, c$, and $d$ because the information on lymph node histology was sometimes inadequate.

\section{Techniques}

Peripheral Blood Cultures.-Cultures of separated lymphocytes were used for chromosome analysis. The method was based on that of Moorhead et al. (1960), the polymorphs, after ingestion of carbonyl iron, being removed by a magnet (Carstairs, 1962). Cultures from the normal controls were harvested after 72 hours and after 120 hours, those from the patients after 72 hours and also in one case after 46 hours, and in 18 cases after 96 and/or 120 hours. Transformation studies with aliquots of the same blood samples were made, the technique described by Pentycross (1968a) being used.

Chromosomes of Bone Marrow and Lymph Nodes.-Bone marrow preparations were made by using a slight modification of the direct method of Tjio and Whang (1962). Chromosome studies on lymph nodes were carried out with cell suspensions from biopsy specimens. In each case an aliquot of suspension was used for making direct preparations. Aliquots of the remaining material were added to $\mathrm{TC} 199$ and $\mathrm{AB}$ serum and incubated at $37^{\circ} \mathrm{C}$. These cultures were harvested after 18 to 24 hours (without phytohaemagglutinin), and after 48 and/or 72 hours (with and without phytohaemagglutinin).

\section{Classification of Chromosomal Complements}

In classifying the chromosomal complements the following criteria were adopted:

Normal Diploid.-A cell with 46 chromosomes and a normal karyotype according to the Denver system (1960). If a chromosome was broken but could be reassembled the cell was classified as a normal one. The cells of a person with a morphological variant were scored under this heading.

Diploid+Fragment.-A diploid cell in which the fragment did not form part of the karyotype.
Hyperdiploid.-A cell with more than 46 chromosomes in which the extra chromosome(s) could be classified in one of the seven groups of the Denver System.

Hyperdiploid with Structural Rearrangement $(R)$.-A cell with more than 46 chromosomes, one or more of which had undergone a structural rearrangement.

Hypodiploid.-A cell with fewer than 46 chromosomes missing one or more from the normal diploid complement.

Hypodiploid with Structural Rearrangement $(R)$.-A cell with fewer than 46 chromosomes, one or more of which had undergone a structural rearrangement.

Pseudodiploid.-A cell with 46 centromeres but with an abnormal karyotype.

In describing abnormal cells the convention used was that of the Chicago Conference (1966).

\section{Chromosomes of Peripheral Blood Lymphocytes}

The chromosome analyses of 600 cells from normal controls and 250 from patients with chronic lymphocytic leukaemia are given in Table I.

\begin{tabular}{|c|c|c|c|c|c|c|c|c|c|}
\hline & \multirow{3}{*}{ 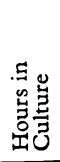 } & \multicolumn{8}{|c|}{ Classification of Cells } \\
\hline & & \multirow{2}{*}{ 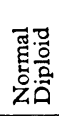 } & \multirow{2}{*}{ 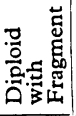 } & \multirow{2}{*}{ 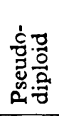 } & \multicolumn{4}{|c|}{ Aneuploid } & \multirow{2}{*}{ Total } \\
\hline & & & & & $<46$ & $<46 \mathrm{R}$ & $>46$ & $>46 \mathrm{R}$ & \\
\hline \multirow{4}{*}{$\begin{array}{l}\text { Normal controls } \\
\text { Normal controls } \\
\text { C.L.L. } \\
\text { untreated .. } \\
\text { C.L.L. given } \\
\text { chemotherapy } \\
\text { C.L.L. given } \\
\text { chemotherapy }\end{array}$} & $\begin{array}{r}72 \\
120\end{array}$ & $\begin{array}{l}257 \\
246\end{array}$ & $\begin{array}{l}0 \\
2\end{array}$ & $\begin{array}{l}0 \\
7\end{array}$ & $\begin{array}{l}35 \\
35\end{array}$ & $\begin{array}{l}6 \\
6\end{array}$ & $\begin{array}{l}2 \\
3\end{array}$ & $\begin{array}{l}0 \\
1\end{array}$ & $\begin{array}{l}300 \\
300\end{array}$ \\
\hline & 72 & 76 & 1 & 1 & 17 & 2 & 1 & 0 & $98^{*}$ \\
\hline & 72 & 62 & 0 & 4 & 5 & 4 & 1 & 1 & 77 \\
\hline & 120 & 62 & 0 & 6 & 4 & 2 & 0 & 1 & 75 \\
\hline
\end{tabular}

\section{Normal Control Data}

Ten healthy people, five males and five females, were selected to cover the age range of the patients. Since, in studying the patients, it was sometimes necessary to incubate the lymphocyte cultures for up to $i 20$ hours in order to increase the yield of mitoses, it was also necessary to find out the effect of this longer culture time in normal controls.

Sixty cells from each individual were analysed, 30 after 72 hours in culture and 30 after 120 hours in culture. It will be noticed (see Table I) that the number of aneuploid cells was not increased at 120 hours, but that the number of pseudodiploid cells was increased. This higher frequency of pseudodiploid cells can be attributed mainly to the effects of simple chromosome breakage rather than to the occurrence of complicated rearrangements or errors in division. Of the seven pseudodiploid cells, three in which the long arms of a number 2 chromosome had been deleted (Fig. 1) were contributed by the eldest control, an 80-year-old woman.

The frequency of breaks at 72 hours was $4 \%$ and at 120 hours $10 \%$.

\section{Patients with Chronic Lymphocytic Leukaemia}

The results of the chromosome studies in the patients shown in Table I have been pooled in the following way: (1) those from patients with chronic lymphocytic leukaemia who were untreated (four females, two males), and (2) those from patients with chronic lymphocytic leukaemia who had been treated with chemotherapy but not with radiotherapy (two females, three males).

In the cultures of 72 hours' duration from the untreated patients the percentage of aneuploid cells was higher than in 
the normal controls. Most of the aneuploid cells were found in the cultures of two of the patients. Random loss of chromosomes was observed in the cells of one male, and preferential loss of $\mathrm{C}$ or $\mathrm{F}$ group chromosomes in the cells from a 70 -year-old woman. The number of rearranged cells was not increased in the untreated patients. The frequency of breaks was $1 \%$.

In the cells of the patients treated with alkylating agents, in some cases combined with prednisone, there was no increase in aneuploidy as compared with the normal controls. However, there was an increase in the proportion of pseudodiploid cells both after 72 hours in culture $0 \%$ in normal controls, $5 \%$ in treated patients) and after 120 hours in culture $(2 \%$ in normal controls, $8 \%$ in treated patients). Whereas the rearrangements involved in the pseudodiploid cells of the normal controls were simply explained (see Fig. 1), some of the cells of the treated patients showed complicated rearrangements (Fig. 2).

It will be noticed (see Table I) that some of the aneuploid cells could not be accounted for by simple non-disjunction but also showed rearrangements of the chromosomes. If these cells are considered together with the pseudodiploid cells, then after 72 hours of culture $2 \%$ of cells from the normal controls and $3 \%$ of cells from the untreated patients show rearrangements. The treated patients showed $12 \%$ of cells rearranged both at 72 and 120 hours (normal controls at 120 hours, $5 \%$ ). The frequency of breaks was $1 \%$ at 72 hours and $8 \%$ at 120 hours.

The majority of the circulating lymphocytes in both groups of patients had a normal karyotype. In the sample as a whole the number of rearranged cells in the untreated patients was not significantly greater than in the normal controls. However, one cell showing a complex type of rearrangement (Fig. 3) was found in the untreated group. The number of rearranged cells is significantly greater in the treated patients both after 72 hours and after 120 hours of culture.

One patient was found to have a constitutional chromosomal anomaly. The abnormal chromosome, a member of the $G$ group with extra short arm material, Gs + , was present in the lymphocytes and also in the cells of her bone marrow and cultured fibroblasts from skin (Fig. 4). Since the frequency of morphological variations of autosomes in the normal population is between 2 and $3 \%$ (Court Brown, 1967) it is likely that the present finding was fortuitous and not directly related to the diseased state. The diploid cells of this patient were therefore regarded as normal.

The results of the chromosome analyses of 264 peripheral blood lymphocytes in 18 patients with lymphoproliferative disorders other than uncomplicated and typical chronic lymphocytic leukaemia are given in Table II.

One patient with chronic lymphocytic leukaemia (Case 1) had, in addition, a malignancy for which she had been treated by irradiation. Another patient (Case 2) was irradiated because of splenic enlargement following the original diagnosis of chronic lymphocytic leukaemia. Six years later he was found to have reticulum-cell sarcoma. Therefore these two patients were not grouped with the other treated chronic lymphocytic leukaemia patients in Table I. The cells of Case 2 showed evidence of radiation damage, otherwise the chromosome findings were not remarkable.

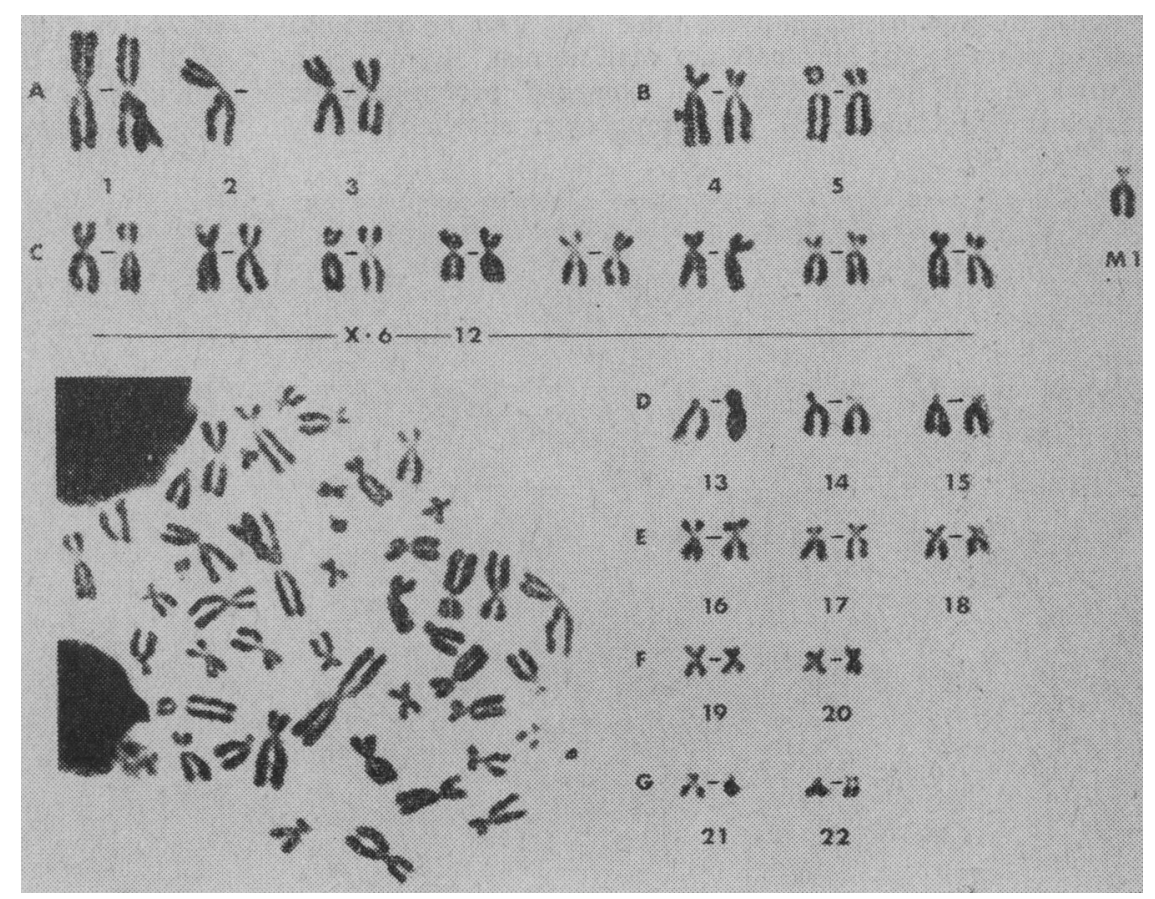

FIG. 1.-Karyotype of pseudodiploid lymphocyte from 80-year-old normal control, showing marker chromosome formed by deletion of the greater part of the long arm of a number 2

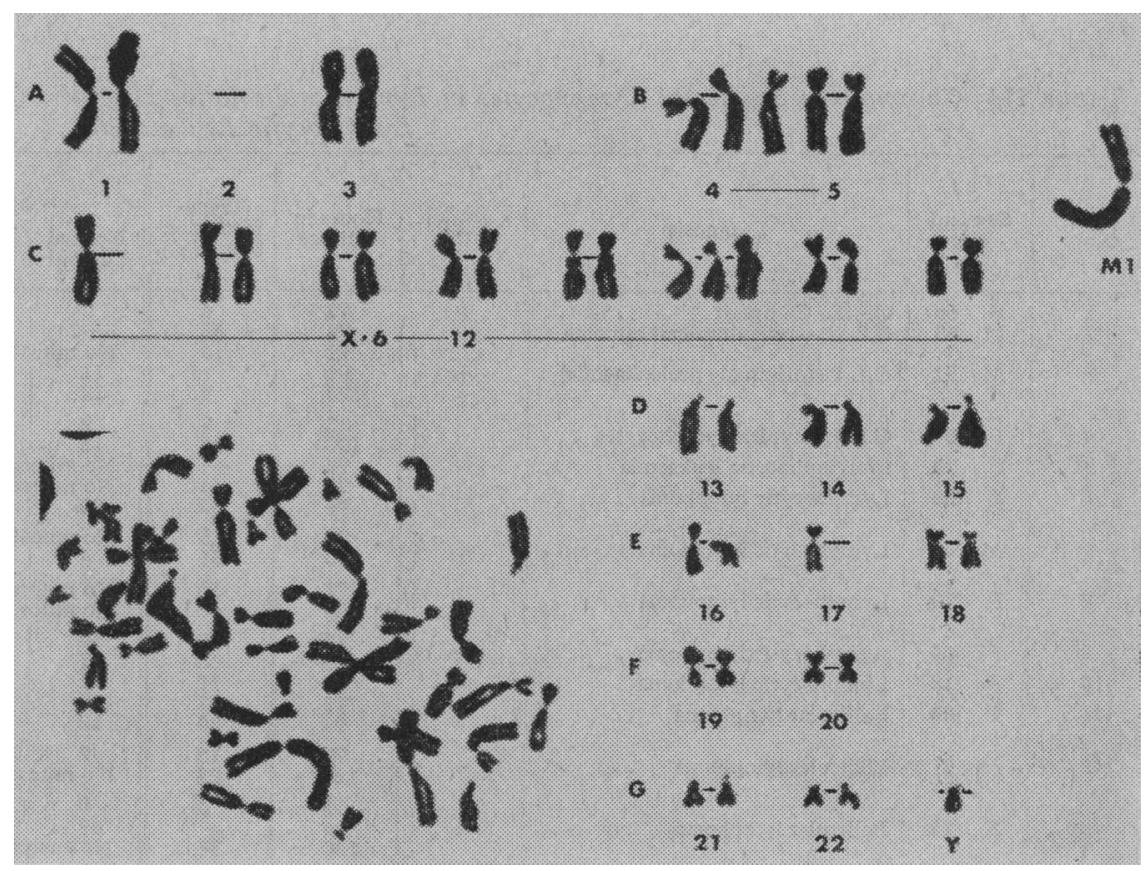

FIG. 2.-Karyotype of pseudodiploid lymphocyte from treated chronic lymphocytic leukaemia patient, showing complex rearrangements and marker chromosome.

\section{Atypical Chronic Lymphocytic Leukaemia}

One patient (Case 3) who presented with lymph node enlargement, without a peripheral blood lymphocytosis, had been treated by irradiation. At the time of investigation he showed 
a peripheral blood lymphocytosis. The results in this patient show very clearly the advantages of increasing the time in culture to improve the yield of cells in mitosis. No mitoses were obtained at 72 hours, but at 96 hours and 120 hours the yield was sufficient to determine that the karyotype was normal.

One patient (Case 4) had morphologically abnormal lymphocytes which in some respects resembled transformed cells. In response to phytohaemagglutinin these cells gave an adequate yield of mitoses: the chromosomes were normal. By contrast, cultures of the patient (Case 5) who had prolymphocytic leukaemia (B.E.C.C., 1963), the lymphocytes showing promi- nent nucleoli, never yielded any mitoses; many of the cells lysed in the cultures.

\section{Lymphocytic Lymphoma}

The patients with lymphocytic lymphoma were interesting in that the lymphocytes of some of them yielded no mitoses in 72-hour cultures, whereas those of one of them gave a high yield at this time. In the cultures from this patient (Case 9) a high proportion of pseudodiploid and rearranged aneuploid cells were observed, $11 / 99$. In six of these rearranged cells the long arms of a C9 chromosome had been deleted with loss of the acentric fragments, the break having occurred in the region of the secondary constriction. Most of the C9 chromosomes of this patient showed attenuation of the secondary constriction, and in some cells the chromosome was broken in this region without loss of fragments.

In addition to the six cells just described, three other cells showed a common abnormality, the deletion of the short arm of a B group chromosome. All the other cells had normal B group chromosomes.

Chromosome analysis was possible in three other patients, including the young woman (Case 10) whose lymph node was reported to contain lymphoblasts. The few analysable peripheral blood lymphocytes had normal chromosomes.

\section{Follicular Lymphoma}

It was difficult to accumulate dividing cells at 72 hours in these cases; the yield was improved at 96 hours. The chromosomes were essentially normal.

FIG. 3.-Karyotype of pseudodiploid lymphocyte from untreated chronic lymphocytic leukaemia patient, showing complex rearrangements and marker chromosomes.

TABLE II.-Chromosome Studies of Lymphocytes in Lymphoproliferative Disorders (Other Than Uncomplicated and Typical Chronic Lymphocytic Leukaemia)

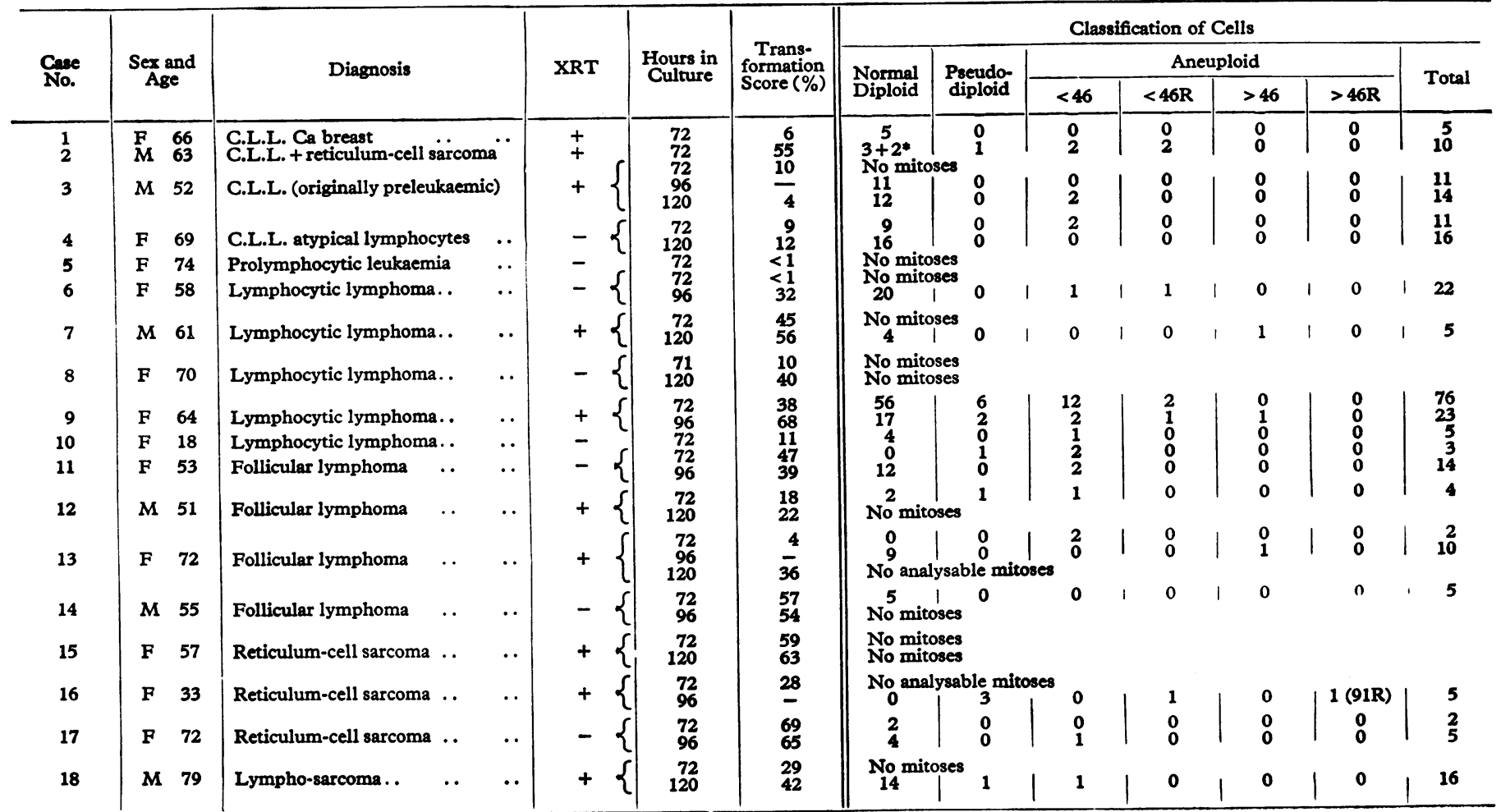

- Diploid + fragment. 


\section{Reticulum-cell Sarcoma}

Very few cells suitable for analysis were obtained. The culture of one patient (Case 16) produced five dividing cells, all of which were abnormal (Fig. 5). The cell illustrated repre-

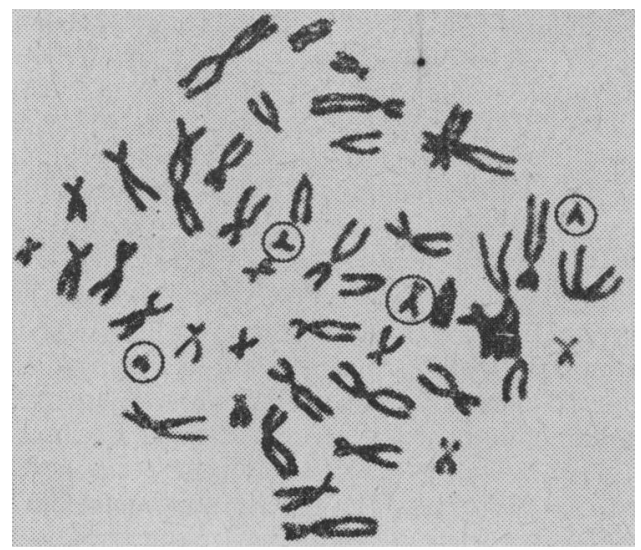

FIG. 4.-Morphological variant in treated chronic lymphocytic leukaemia patient. The $G$ group of chromosomes is ringed; one of the group has prominent short arms, Gst.

sents the basic karyotype apart from the loss of an E group chromosome. All the cells had the same marker chromosomes, and in the cell with 91 chromosomes they were present in duplicate.

\section{Lymphosarcoma}

An adequate number of normal cells was obtained from a single case by culturing the lymphocytes for 120 hours. No mitoses were obtained at 72 hours.

\section{Lymphocyte Transformation Studies}

Among the normal controls in this study the mean transformation score was $47 \%$ at 72 hours and $55 \%$ at 120 hours. All the patients pooled in Table I had transformation scores well below the normal limit (36\%). Lymphocyte transformation was studied in three of the treated patients with chronic lymphocytic leukaemia at 120 hours as well as at 72 hours. At 72 hours the scores were $3 \%, 11 \%$, and $0.3 \%$, and the corresponding scores at 120 hours were $6 \%, 8 \%$, and $1.5 \%$.

The transformation scores of the other patients studied are given in Table II. The scores showed considerable variation, of ten being within the normal range, which in our laboratory is between 36 and $60 \%$. In the patients with lymphocytic lymphoma the score was increased if the culture time was extended. In the remainder of the patients the effect of prolonged culture time was variable.

\section{Chromosomes of Bone Marrow}

In an untreated patient with chronic lymphocytic leukaemia 10 cells were found to be normal and one cell lacked an E group chromosome. Only two cells were suitable for analysis in a treated case of chronic lymphocytic leukaemia; both were normal apart from the morphological variant $(\mathrm{Gs}+)$.

In two cases of lymphoma (Cases 8 and 12) in which there was histological evidence of bone marrow infiltration no cells with abnormal chromosomal complements were found. No abnormality was detected in two patients with reticulum-cell sarcoma (Cases 16 and 17), whose bone marrows were not infiltrated. Terminally, Case 16 had chromosomally abnormal cells in the peripheral circulation.

\section{Chromosomes of Lymph Nodes}

Information about the karyotypes of lymph-node cells was available in five cases. The chromosomal findings in the lymph nodes in Cases 2 and 12 have been reported by Millard (1968). Lymph node biopsy material was received from three other patients-one from a case of untreated chronic lymphocytic leukaemia included in Table I, and from Cases 13 and 17 (Table II).

The direct preparation of the lymph node from the patient with chronic lymphocytic leukaemia produced only one cell, and this was normal. After culture for 68 hours with phytohaemagglutinin normal cells, or aneuploid cells with random loss, were obtained. The node of Case 2 (Case 10 of Millard) yielded predominantly regular tetraploid cells in a 24-hour culture and normal cells after stimulation with phytohaemagglutinin. It is probable that the tetraploid cells represented the tumour cells. No tetraploid cells were found in the peripheral blood culture.

In two patients with follicular lymphoma (Cases 13 and 12Case 5 of Millard) no normal cells were found in the direct preparations. Both patients had hyperdiploid cells with vari-

arcoma-hyperdiploid cells (modal number 49) were found directly, after 24 hours in culture, and after 48 and 72 hours with phytohaemagglutinin. No normal female cells were found among the 30 analysed. The karyotypes of the cells varied; in $\mathbf{1 5}$ of the $\mathbf{3 0}$ cells a B group chromosome was found to have

able karyotypes, with a constant rearrangement of the A group in Case 12 and a loss of $\mathrm{E}$ and $\mathrm{F}$ group chromosomes and gains of $\mathrm{C}$ group ones in Case 13. Diploid cells, probably normal lymphocytes, were found in 72-hour cultures with phytohaemagglutinin of the nodal cells in Case 13. In neither of these patients were any hyperdiploid cells resembling the nodal ones found in the peripheral blood cultures.

In the lymph node of Case 17-a case of reticulum-cell 
a deletion in the short arm $(\mathrm{Bp}-)$. In the direct preparation only two out of nine cells had identical karyotypes (49, Bp-, $\mathrm{C}+2, \mathrm{D}+, \mathrm{E}+, \mathrm{F}-), 3$ out of 11 cells in the 24-hour culture had the same karyotype as each other $\left(49, A_{+}, C_{+}, D_{+}\right.$, $\mathrm{E}+, \mathrm{F}-$ ) and two cells in the 72-hour culture with phytohaemagglutinin were the same $(49, \mathrm{C}+2, \mathrm{D}+, \mathrm{E}+, \mathrm{F}-)$. Otherwise the karyotype of each of the cells was unique. All the cells belonged to the abnormal population with the exception of a cell with 45 chromosomes $(\mathrm{C}-$, ace + ) in the 72-hour culture with phytohaemagglutinin. This was considered to be a normal lymphocyte in division in which a $\mathrm{C}$ group chromosome had broken.

\section{Discussion}

\section{Peripheral Blood Lymphocytes}

\section{Chromosomes}

Increasing the time in culture from 72 to 120 hours, in the normal controls selected for this study, did not result in an increase of aneuploid cells, but more cells showing rearrangement due to chromosome breakage at specific regions were observed.

The majority of the cells of both treated and untreated patients with chronic lymphocytic leukaemia had a normal karyotype. We do not agree with Goh (1967) that there is a high frequency of pseudodiploid cells in untreated patients.

The aneuploid cells from the untreated patients were probably due to random losses except for the contribution made by a 70-year-old woman, most of whose aneuploid cells lacked a C group chromosome. A tendency to an increased loss of C group chromosomes in lymphocytes has been described among a certain group of women over 65 years of age, in three studies of the relation between aneuploidy and ageing (Jacobs et al., 1963 ; Hamerton et al., 1965 ; Sandberg et al., 1967).

The main feature of the cells of patients treated with alkylating agents, in some cases combined with prednisone, was an increase of rearranged cells both after 72 and after 120 hours in culture. The question arises whether the rearranged cells in the treated group could be attributed to treatment. Prednisone has been shown to have a cytocidal action on lymphocytes in vitro, particularly in chronic lymphocytic leukaemia (Schrek, 1964), and to inhibit mitosis in vitro (Nowell, 1961), but it has not been implicated in chromosome damage. Alkylating agents, on the other hand, are known to react with deoxyribonucleic acid, and therefore rearrangements of the chromosomes due to breakage are a theoretical possibility, particularly in the case of precursor cells. However, it must be appreciated that when these drugs are successful in controlling the total leucocyte count in patients with chronic lymphocytic leukaemia some of the cells that are eliminated must be in interphase, and so they probably die without going into a subsequent division cycle. The possibility remains open, therefore, that the increase in rearranged cells in this particular group of patients may be attributed to a fundamental disorder of a minority of the cells rather than to the effects of the therapy. The differences between the treated and the untreated patients might be associated with the selection of cases requiring treatment.

Among the five patients with lymphocytic lymphoma one was found to have several peripheral blood lymphocytes with abnormal karyotypes, six of which had their origin in breakage of a $\mathrm{C} 9$ chromosome in the region of the secondary constriction. We concluded that in vitro breakage in this specific region, followed by funther cell division(s) with consequent loss of acentric fragments, resulted in the appearance of these abnormal cells. In the lymphocytes of one of the normal controls we observed pseudodiploid cells that had resulted from breakage of a sensitive region of a number 2 chromosome (see
Fig. 1). In the case of the patient the propensity to breakage of the C9 chromosome may have been influenced by therapy. In this context it is interesting to note that substances which can induce chromosomal breakage in vitro-for example, mitomycin C-show a preference for the areas of secondary constrictions (Cohen and Shaw, 1964). It is conceivable that three other abnormal cells from this patient represented a clone, possibly radiation-induced. Their karyotypes were not identical, but the abnormalities were present in cultures done on different dates. Though radiation-induced clones are usually stable, clonal variants may occur. In lymphocytes radiationinduced clones with stable abnormalities are comparatively rare. In a study of 133 irradiated patients unequivocal evidence of the presence of more than one cell of a similar karyotype was found in only four patients (Court Brown et al., 1967).

Among the patients having other lymphoproliferative disorders, a culture from a patient with reticulum-cell sarcoma yielded only five cells, all of which were abnormal and contained marker chromosomes. The cells were either members of a radiation-induced clone of lymphocytes or circulating tumour cells in division. The type of rearrangement was compatible with either view. The fact that the patient was in the terminal stages of her illness, with widespread dissemination of the disease, favours the interpretation of tumour cells. No tumour cells were seen, however, in a peripheral blood smear made a few days after the blood culture. In our experience it is most unusual for cells with high chromosome numbers from lymphomatous tumours to be found in division beyond 24 hours of in vitro culture. Even if the abnormal cells in the diploid range were tumour cells it seems likely that the rearranged hypotetraploid cell, with the marker chromosomes in duplicate, arose in culture by a nuclear division not accompanied by a cytoplasmic one.

Increasing the time in culture usually improved the yield of mitoses in chronic lymphocytic leukaemia, lymphocytic lymphoma, and lymphosarcoma, and also in some cases of reticulum-cell sarcoma and follicular lymphoma. The cells seen in mitosis at 96 or 120 hours could represent an accumulation of cells that have gone through several division cycles. Alternatively, they could represent a larger population of cells with a delayed response to phytohaemagglutinin.

\section{Transformation Studies}

The normal controls selected for this study all had transformation scores, at 72 hours, within the limits defined by previous studies on a larger sample of normal individuals (Pentycross, 1968b).

All the patients with chronic lymphocytic leukaemia had transformation scores well below the normal limit. Variable scores were found in the patients with other lymphoproliferative disorders. For comparison, the range of the transformation scores at 72 hours in normal controls and in patients with chronic lymphocytic leukaemia, other lymphoproliferative disorders, and Hodgkin's disease are given in Fig. 6 . The data from which the figure was compiled include cases additional to those recorded here (Pentycross, 1968c). The cases with Hodgkin's disease have been published previously (Lawler et al., 1967).

Though the mean transformation score for the 10 normal people studied was significantly increased at 120 hours (47$55 \%$, changes of $6 \%$ or more being regarded as significant), there was considerable individual variation.

In the three treated chronic lymphocytic leukaemia patients whose lymphocytes were cultured for 120 hours as well as 72 hours, prolonging the culture time produced only marginal changes (in one instance a reduction) in transformation scores. It is interesting to speculate that in the two instances in which a slight increase occurred a further improvement in score might have resulted from prolonging the culture time even further. 


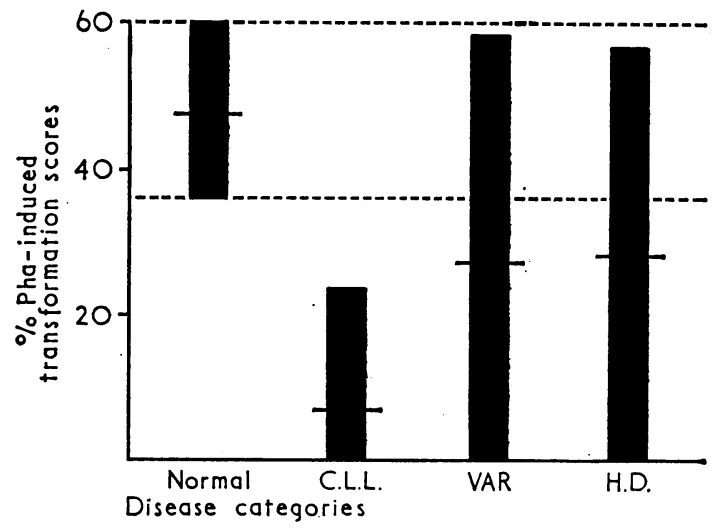

FIG. 6.-Lymphocyte transformation in various lymphoproliferative disorders. Range and mean. C.L.L.=Chronic lymphocytic leukaemia. Var = Other lymphoproliferative disorders. H.D.=Hodgkin's disease. P.H.A.= Phytohaemagglutinin.

Only in lymphocytes from patients with lymphocytic lymphoma did an increase in transformation score consistently occur when the culture time was prolonged.

Mitotic yields in the chromosome cultures were sometimes meagre even when the transformation score was within normal limits. We have studied a normal individual, additional to those described here, whose lymphocytes gave a normal transformation score, but the mitotic yield, as measured by mitotic index, was always very low. Thus the number of cells showing morphological transformation in response to phytohaemagglutinin is not necessarily directly proportional to the number of cells in division at a given time.

\section{Chromosomes of Bone Marrow}

Mitotic yields from the bone marrow of patients with chronic lymphocytic leukaemia are often poor, presumably because of the infiltration of the bone marrow with lymphocytes that are not actively dividing in vivo. The reports of Sandberg et al. (1960, 1961) and Kinlough and Robson (1961) contain information on the chromosome counts of bone marrow cells from seven untreated patients with chronic lymphocytic leukaemia. Of the 156 cells recorded, six were hyperdiploid and eight were tetraploid. As adequate data on bone marrow cells from normal controls do not exist it is difficult to assess the significance of the possibly raised proportion of hyperdiploid cells. No hyperdiploid cells were found in the bone marrow of the untreated patient with chronic lymphocytic leukaemia whom we examined.

Sandberg et al. (1964) and Sasaki et al. (1965) have described the presence of abnormal cells in preparations from bone marrows showing histological evidence of infiltration with lymphosarcoma or reticulum-cell sarcoma. In one case the cells of the bone marrow were shown to have the same karyotype as the cells of the involved node (Sasaki et al., 1965). Our two cases showing histological infiltration did not have cells with abnormal karyotypes in the bone marrow.

\section{Chromosomes of Lymph Nodes}

In chronic lymphocytic leukaemia the yield of dividing cells in direct preparations of lymph nodes is unlikely to be high because the bulk of the tissue consists of small lymphocytes. Chromosomal abnormalities have not been found in these cells (Trujillo et al., 1967). The few cells that are found in division may be participating in an immune or inflammatory reaction but are not necessarily of lymphocytic origin. When the lymphocytes of the lymph nodes are stimulated with phytohaemagglutinin the mitotic yields are sometimes low (Millard, 1968), as might be expected on the basis of the poor response of peripheral blood lymphocytes in chronic lymphocytic leukaemia.

In the other lymphoproliferative disorders some cells with an abnormal karyotype are almost always found in direct preparations or short-term cultures of the nodes (Baker and Atkin, 1965 ; Miles et al., 1966 ; Millard, 1968). These abnormal cells probably represent dividing tumour cells. Cultures of the nodes with phytohaemagglutinin in these cases usually yield mostly normal cells, presumably derived from normal lymphocytes. Similarly, it is unusual to find cells with an abnormal karyotype, similar to that of the tumour cells of the node, among the lymphocytes of peripheral blood. Examples of the dissemination of abnormal cells in bone marrow and peripheral blood have been described in a case of reticulum-cell sarcoma (Sasaki et al., 1965). In one of the cases of reticulum-cell sarcoma that we studied tumour cells were probably present in the peripheral blood in the terminal stages.

Occasionally, even in lymph node cultures stimulated with phytohaemagglutinin, normal cells may not be found, as for example, in one of our patients (Case 17) with reticulum-cell sarcoma. The lymphocytes in the node failed to respond to phytohaemagglutinin, whereas the response of the peripheral blood lymphocytes was good, and they had normal karyotypes.

We wish to thank the consultant staff at the Royal Marsden and Hammersmith Hospitals for access to their patients, Mrs. M. Martineau and Dr. R. Millard for criticizing the manuscript, and Miss S. Single for technical assistance.

One of us (C. R, P.) gratefully acknowledges a grant from the Leukaemia Research Fund Ltd. in support of his work.

Requests for reprints should be addressed to Dr. S. D. Lawler, Department of Clinical Research, Royal Marsden Hospital, London S.W.3.

\section{REFERENCES}

Baker, M. C., and Atkin, N B. (1965). Brit. med. f., 1, 770.

Baker, M. C., and Atkin, N B. (1965). Brit. med. F., 1, 770. Part 2 , p. 175. London.

Carstairs, K. (1962). Lancet, 1, 829.

Chicago Conference (1966). Standardization in Human Cytogenetics, edited by D. Bergsma. Birth Defects, original article series, II, No. 2. New York.

Cohen, M. M., and Shaw, M. W. (1964). F. Cell Biol., 23, 386.

Court Brown, W. M. (1967). Human Population Cytogenetics, p. 23. Amsterdam.

Court Brown, W. M., Buckton, K. E., and Langlands, A. O. (1967). Int. F. Radiat. Biol., 13, 155.

Denver System (1960). Lancet, i, 1063.

Fitzgerald, P. H., and Adams, A. (1965). F. nat. Cancer Inst., 34, 827.

Fitzgerald, P. H., Crossen, P. E., Adams, A. C., Sharman, C. V., and Gunz, F. W. (1966). f. med. Genet., 3, 96.

Galton, D. A. G. (1963). M.D. Thesis, Cambridge University.

Goh, K. O. (1967). 7. Lab. clin. Med., 69, 938.

Gun, F W Frit. med. 7., 2 1097 .

Hamerton, J. L., 'Taylor, A. I., Angell, R., and McGuire, V. M. (1965). Nature (Lond.), 206, 1232.

Jacobs, P. A., Brunton, M., Court Brown, W. M., Doll, R., and Goldstein, H.' (1963). Nature (Lond.), 197, 1080.

Kinlough, M. A., and Robson, H. N. (1961). Brit. med. 7., 2, 1052

Lawler, S. D., Pentycross, C. R., and Reeves, B. R. (1967). Brit. med. f., 3, 704 .

Miles, C. P., Geller, W., and O'Neill, F. (1966). Cancer (Philad.), 19, 1103.

Millard, R. E. (1968). Europ. 7. Cancer, 4, 97. . J., Battips, D. M., and Hungerford, D. A. (1960). Exp. Cell Res., 20, 613.

Nowell, P. C. (1961). Cancer Res., 21, 1518.

Pentycross, C. R. (1968a). F. clin. Path., 21, 175.

Pentycross, C. R. (1968b). Ph.D. thesis, London University.

Pentycross, C. R. (1968c). Unpublished observations.

Sandberg, A. A., Koepf, G. F., Crosswhite, L. H., and Hauschka, T. S. (1960). Amer. F. hum. Genet., 12, 231.

Sandberg, A. A., Ishihara, T., Miwa, T., and Hauschka, T. S. (1961). Cancer Res., 21, 678.

Sandberg, A. A., Ishihara, T., Kikuchi, Y., and Crosswhite, L. H. (1964). Cancer (Philad.), 17, 738.

Sandberg, A. A., Cohen, M. M., Rimm, A. A., and Levin, M. L. (1967). Amer. f. hum. Genet., 19, 633.

Sasaki, M. S., Sofuni, T., and Makino, S. (1965). Cancer (Philad.), 18, 1007 .

Schrek, R. (1964). F. nat. Cancer Inst., 33, 837.

Tjio, J. H., and Whang, J. (1962). Stain Technol., 37, 17.

Trujillo, J. M., et al. (1967). Cancer (Philad.), 20, 215. 